\title{
Cultura, mídias e identidades na Pós-modernidade
}

\author{
Lidia Miranda Coutinho* \\ Elisa Maria Quartiero**
}

\section{Resumo:}

Neste artigo buscamos relacionar o fenômeno da globalização às questões culturais, formação de novas identidades e à crescente expansão das mídias nas sociedades contemporâneas. Discutimos a construção das novas identidades culturais que emergem frente à globalização, fruto da imbricada relação das identidades individuais, coletivas e midiáticas. Contextualizamos o espaço e o lugar que as mídias eletrônicas ocupam nestes tempos de pós-modernidade a partir do conceito de midiatização da sociedade e discutimos as possibilidades que a teoria dos modos de endereçamento traz para o entendimento da relação entre mídia, currículo e escola.

Palavras-chave: Identidade. Mídia. Identidade e cultura na pós-modernidade.

Mestre em Educação pela Faculdade de Educação (FAED) da Universidade do Estado de Santa Catarina (UDESC). Atua no Instituto Sapientia/Fundação de Estudos e Pesquisas Sócio-Econômicos - FEPESE.

** Doutora em Mídia e Conhecimento pela Pós-graduação em Engenharia de Produção (PPGEP) da Universidade Federal de Santa Catarina (UFSC). Professora no Centro de Ciências Humanas e da Educação da Universidade do Estado de Santa Catarina (UDESC). 


\section{O conceito de Cultura e os Estudos culturais}

Para teorizar e estudar as mídias é produtivo tratar, primeiramente, do contexto mais amplo no qual esses meios se inserem: a cultura. A definição de cultura foi sendo formulada, ao longo dos séculos, sobretudo pela antropologia e ciências sociais, dentro das quais se desenvolveram os estudos culturais, fundamentais para a formulação de um conceito atual e complexo de cultura.

Os estudos culturais surgiram com base em pesquisas e publicações na década de 1950 de Richard Hoggart (The uses of Literacy, 1957), Raymond Williams (Cultura e Sociedade, 1958) e E. P. Thompson (The Making of the English Working-class, 1963). Esses autores, em especial Williams (1992) e Thompson (1991), com seus consensos e dissensos, ${ }^{1}$ formularam a tese de que a palavra cultura traz em si questões "propostas pelas grandes mudanças históricas que as modificações na indústria, na democracia e nas classes sociais representam de maneira própria e às quais a arte responde também, de forma semelhante.” (HALL, 2003, p. 125).

Williams (1992), na obra citada, traça a revisão histórica do conceito de cultura construído pela sociedade e contesta a ideia à época vigente - década de 50 do século XX - de cultura (superior e inferior, popular e erudita, culta e de massa), originária da tradição e do Romantismo. Segundo este autor, a cultura não deve ser resumida a questões de ordem econômica e política e não é prerrogativa de uma ou outra classe social economicamente privilegiada. A cultura é comum a todos, é ordinária, faz parte do viver em sociedade, sendo construída na inter-relação das práticas sociais e configurando-se como elemento fundamental para o entendimento de quem somos e para aonde estamos indo (ARAÚJO, 2004). Ela é produto de relações sociais, da língua, das tecnologias, da escrita, dos mecanismos de comunicação e, para compreendê-la, é necessário descrever e analisar essas relações e seus esquemas complexos. A estrutura social "está" no produto, portanto as mudanças na produção cultural - sejam elas estruturais, estéticas, de modelo ou estilo - são fruto de mudanças concretas, sempre sociais e históricas. Em resumo: a principal contribuição de Williams foi ampliar o conceito de cultura como modos de vida, sistema de significações e produto/atividade artística e intelectual, concomitantemente. Ele propõe, por conseguinte, uma análise da cultura que começa com a descoberta dos 
padrões característicos "através do estudo da organização geral de um caso particular", tendo como propósito "entender como as interrelações de todas essas práticas e padrões são vividas e experimentadas como um todo, em um dado período: essa é sua estrutura da experiência (structure of feeling).” (HALL, 2003, p. 128).

Outro importante autor dos estudos culturais, que conferiu visibilidade mundial a esse campo, e que se dedica a desenvolver reflexões sobre a questão da globalização e das identidades pós-modernas, é Stuart Hall. Suas pesquisas, iniciadas na década de 1960, abordam as práticas da mídia relacionando-as às estruturas sociais de maneira que ao analisar o efeito daquelas sobre os receptores são consideradas as múltiplas culturas, repletas de conflitos e disputas de poder entre grupos. A recepção passa, então, a ser entendida como um processo social complexo de apropriações, usos e reelaborações de conteúdos. Hall (2003, p. 133), fazendo uma análise do percurso que os estudos culturais traçaram ao longo dessas mais de quatro décadas, afirma que o paradigma dominante atual "conceitua a cultura como algo que se entrelaça a todas as práticas sociais; e essas práticas, por sua vez, como uma forma comum de atividade humana: como práxis sensual humana, como a atividade mediante através da qual homens e mulheres fazem a história."

\section{Globalização e identidades líquidas}

A questão cultural ganhou visibilidade nos tempos atuais frente às crescentes discussões que se travam em âmbitos os mais diversos (governos, iniciativa privada, academia, sociedade) em torno da globalização. A obra de Bauman, em especial seus livros Modernidade Líquida (2000), Comunidade (2003), Globalização: as consequências humanas (1999) e Identidade (2005), traça um painel sobre a globalização na atualidade, suas causas e consequências, sem pretender uma definição para este acontecimento tão complexo, estabelecendo conexões com fenômenos sociais, políticos e econômicos que, a primeira vista, parecem não ter relação com a temática. Entre as principais consequências deste processo, em curso no mundo inteiro com diferentes intensidades, o autor elenca: o esvaziamento das instituições de representação democrática; a modificação completa das relações interpessoais e de trabalho; a constituição de uma nova produção 
cultural e intelectual; a modificação da noção de tempo e distância; o questionamento da noção de pertencimento e a formação de novas e fluidas, transitórias, identidades sociais, culturais e mesmo sexuais.

Bauman defende que a globalização é uma grande transformação mundial relacionada à perda de solidez do estado-nação, antes indivisível, protetor e soberano, que perdeu o controle - ou ainda o detém de maneira enfraquecida - sobre as três esferas de direitos propostas por Marshall (1967), ${ }^{2}$ produzindo o colapso do Estado de Bem-Estar Social. O princípio do estado-nação, relacionado à natividade, soberania de terras, recursos naturais e produtos do trabalho, é o que havia mantido o ideário de uma identidade nacional forte, inquestionável e indivisível e estabelecido uma ordem para a questão. Ao contrário das outras identidades, a identidade nacional conseguia estabelecer, sem conflito algum, a linha divisória entre o "nós" e o "eles", corroborada por documentos internacionalmente reconhecidos. Outras identidades, consideradas menores, não ameaçavam a identidade nacional, pois não eram concorrentes e sim complementares.

É importante ressalvar que o pertencimento a uma nação, por mais natural e evidente que possa parecer, é uma convenção, cultivada e aprendida pelas pessoas ao longo da história das sociedades e que se tornou parte conformadora do homem moderno. Quando o poder unificador do estado-nação começou a fraquejar, devido a um pensamento capitalista liberalizante que se pulverizou mundialmente, resultando em perda de garantias, segurança e privilégios para seus membros, a identidade nacional em crise perdeu "suas âncoras sociais que a faziam parecer tão natural, predeterminada e inegociável” (BAUMAN, 2005, p. 30), começando a fracassar como conceito. A questão da identidade, então, entrou na linha de discussão como uma das relevantes na atualidade. Segundo Bauman (2005, p. 17),

tornamo-nos conscientes de que o "pertencimento" e a "identidade" não têm a solidez de uma rocha, não são garantidos para toda a vida, são bastante negociáveis e revogáveis, e de que as decisões que o próprio indivíduo toma, os caminhos que percorre, a maneira como age - e a determinação de se manter firme a tudo isso - são fatores cruciais tanto para o 'pertencimento' quanto para a 'identidade'. 
A identidade, o 'eu postulado', está relacionada às heranças sociais, culturais e definições anteriores ao sujeito. Diz-se que há as comunidades de vida ou nascimento e as comunidades de destino formadas por ideias, hábitos costumes, escolhas culturais, estéticas etc.. As identidades se formam pela vivência nessas comunidades e a constatação dessa identidade ocorre às pessoas porque ainda vigora o sentimento de pertencimento a algum lugar, alguma cultura, cidade, bairro, comunidade, grupo de ideias e princípios. Mas, à medida que as pessoas são expostas a muitas e diferentes comunidades de destino e passam a refletir sobre esse fato, a definição de identidades torna-se problemática.

A discussão sobre a identidade, segundo Bauman (2005), é profícua e necessária, porém, muitas vezes, equivocada quando se volta para a busca de respostas definitivas e tranquilizadoras. A identidade é tema intangível na modernidade líquida, porque até mesmo identidades aparentemente sólidas, como raça e classe social, são questionadas, revistas, sobrepostas, fundidas, combinadas. As identidades fixas de outrora, plenamente definidas, recortadas e desprovidas de ambiguidade, parecem não mais funcionar e passamos a buscar "identidades em movimento - lutando para nos juntarmos aos grupos igualmente móveis e velozes que procuramos, construímos e tentamos manter vivos por um momento, mas não por muito tempo." (BAUMAN, 2005, p. 32, grifos do autor). Manter-se em movimento deixa de ser uma opção: torna-se uma obrigação para aqueles que se pretendem incluídos.

Pessoas participam de grupos, de comunidades de destino específicas, em busca de novidades, mas também de proteção, familiaridade e, às vezes, de um pouco de presença física contínua, que a modernidade líquida parece desdenhar. Essas comunidades representam abrigo em meio à globalização planetária, ao mesmo tempo atraente e assustadora. Mas, como as relações sociais modificadas da atualidade, se comparadas às relações modernas, são formadas por laços sociais frouxos que se desfazem e se renovam com relativa facilidade, essas comunidades de destino são prontamente substituídas por outras, nos rastros da novidade, o que leva Bauman (2005, p. 19) a afirmar que

em nossa época líquido-moderna, o mundo em nossa volta está repartido em fragmentos mal coordenados, enquanto as nossas existências individuais são fatiadas numa sucessão de episódios fragilmente 
conectados. Poucos de nós, se é que alguém é, são capazes de evitar a passagem por mais de uma 'comunidade de ideias e princípios', sejam genuínas ou supostas, bem integradas ou efêmeras, de modo que a maioria tem problemas em resolver (para usar os termos cunhados por Paul Ricoeur) a questão da la mêmete (a consistência e continuidade da nossa identidade com o passar do tempo).

Hall (2005, p. 7), ao analisar a formação de múltiplas identidades na pósmodernidade, também defende que essa questão está sendo muito discutida porque se acredita que "velhas identidades, que por tanto tempo estabilizaram o mundo social, estão em declínio, fazendo surgir novas identidades e fragmentando o indivíduo moderno". O sujeito pós-moderno transforma-se em um indivíduo descentrado e sem identidade engessada e "a identidade torna-se uma 'celebração móvel': formada e transformada continuamente em relação às formas pelas quais somos representados ou interpelados nos sistemas culturais que nos rodeiam.” (HALL, 2005, p. 13).

Outro tema emergente nas discussões sobre globalização é a modificação da relação temporal/espacial devido ao alargamento das fronteiras geográficas que são hoje facilmente ultrapassadas, o que transforma a distância em um produto social e não mais um dado objetivo, físico. O grande desafio é o rompimento das barreiras econômicas o que, por sua vez, permite romper barreiras geográficas, estatais, nacionais e identitárias. Próximo é o que se torna familiar, habitual, corriqueiro. Longe é o inacessível, inalcançável. Esta nova configuração polariza as diferenças e a exclusão porque dá apenas a alguns a possibilidade de escolha da territorialidade e das identidades desejadas.

No período pré-moderno, defende Bauman (2005), a identidade era determinada pelo nascimento com poucas oportunidades de ascensão e menos espaço para questionamentos do tipo "quem eu sou, a quais grupos pertenço". Na modernidade, a identidade humana era determinada principalmente pelo papel produtivo que a pessoa desempenhava, isto é, por sua colocação na pirâmide do mercado de trabalho. Na modernidade líquida a identidade está calcada no papel consumidor que a pessoa é capaz de exercer. A articulação e a desarticulação de identidades, esse poder de escolha mais ou menos consciente, está relacionado à hierarquia sócio-econômica 
emergente. Os privilegiados nessa cadeia escolhem, num leque de amplas opções, as identidades mais ou menos convenientes a cada momento.

Da mesma forma que adquirem produtos, lugares e experiências, constroem para si novas e fugidias identidades que, ao se mostrarem obsoletas, são rapidamente substituídas por outras ainda mais atuais. Assim como roupas, carros e destinos, identidades entram e saem de moda. E quem for capaz de acompanhar essa volatilidade identitária estará no topo do mundo líquido. Os outros, distribuídos por todos os espaços do mundo globalizado, permanecem mais ou menos resignados às suas identidades fixas e estigmatizadas (BAUMAN, 2005, p. 44). A questão da mobilidade identitária torna-se problema apenas para as pessoas que têm consciência crítica de sua mobilidade limitada e de que muito mais recebem produtos culturais extraterritoriais, tornando-se simbolicamente grandes receptores. A ideia de globalização presente no senso comum é de que a liberdade do capital gera um mundo livre e democrático e que ela é um processo desarticulado, no qual não existe um centro emissor de informações, produtos e bens simbólicos. Tem-se a equivocada impressão de que essas questões estão pulverizadas, desorganizadas. Um questionamento que pode nos ajudar a ter uma visão mais crítica sobre isso é: estamos globalizando ou sendo globalizados? Podemos dizer, grosso modo, que todos globalizam e são globalizados, mas não da mesma forma e com igual intensidade.

A globalização não parece implicar, como crêem vários autores, uma homogeneização econômica ou cultural. Ocorrem hibridizações e as diferenças permanecem, reconfiguradas. A globalização, afirma Canclini (2005, p. 11), é um processo de "reordenamento das diferenças e desigualdades, sem suprimi-las: por isso, a multiculturalidade é um tema indissociável dos movimentos globalizadores." Este autor, analisa os processos de deslocamentos da influência e subordinação latino-americana da Europa para os Estados Unidos e avalia que tal deslocamento não é uma simples mudança de senhor, mas uma grande modificação na natureza da relação. Ao mesmo tempo em que países da Europa exploraram as colônias latino-americanas, influenciaram, em grande medida, suas constituições e regimes políticos e ajudaram a formar as instituições de representação democrática e popular e os movimentos sociais. As relações de subordinação que se formam com os Estados Unidos, de formas distintas, estão relacionadas "aos mercados agrícolas, industriais e financeiros, à 
produção, circulação e consumo de tecnologia e cultura, e aos movimentos populacionais - turistas, migrantes, exilados.” (CANCLINI, 2005, p. 12).

\section{A midiatização da sociedade: um conceito para entender os meios de comunicação}

Os processos de comunicação, até algumas dezenas de anos atrás, diziam respeito quase que exclusivamente à comunidade, ao ser-em-comum. Tinham relação com o vínculo-social que as pessoas estabeleciam umas com as outras, com a necessidade de participar, de interagir, de se expressar, de ser compreendido e de compreender o outro. Na contemporaneidade, comunicar-se significa também 'participar' do que acontece para além de nossas limitações físicas e domínios materiais e imateriais. Significa fazer parte de uma cultura de massa ${ }^{3}$ de um campo de extrema sofisticação técnica e simbólica, cujos produtos são formados de referências e linguagens múltiplas, e representam mais do que mero entretenimento e/ou informação: são produtores de sentidos, exemplificadores de comportamentos, produtores e reprodutores de valores sociais e morais, modos de ver e de ser no mundo. As mídias atuais afetam maneiras tradicionais de comunicação, modificam códigos e conteúdos semânticos, influenciam e são influenciadas pela sociedade e geram mudanças no pensamento e na ação. Nossas linguagens são profundamente tocadas por elas, assim como nossos sistemas de crenças e de códigos historicamente produzidos.

Sodré (2006), em uma linha de pensamento crítico quanto ao lugar e poder dos meios de comunicação de massa na sociedade atual, defende que vivemos um cenário de midiatização das relações sociais, em que as pessoas, cada vez mais, se realizam sendo audiência. Paralelo a isso, diminui a mediação de instituições formadoras tradicionais como a família, a escola e os grupos de pertença, substituídas pelas “tecnomediações". O autor define as "tecnomediações" como "uma espécie de prótese tecnológica e mercadológica da realidade sensível, denominada medium", um tipo particular de interação e presença em que as relações humanas tendem a telerrealizar-se ou virtualizar-se (SODRÉ, 2006, p. 20). Tendo como referência Aristóteles, mais especificamente a obra Ética a Nicômaco (1973), em que o filósofo grego define os modos de existência na Pólis: bios theoretikos (vida contemplativa), bios politikos (vida política), bios apolaustikos (vida prazerosa), Sodré cria uma quarta esfera existencial que reflete 
essa nova interação/presença no mundo: o bios da tecnocultura, detentor de espaço próprio e autônomo cuja característica marcante é o grau elevado de indiferenciação entre o homem e sua imagem. Este quarto bios implica uma nova configuração mental e perceptiva ao estabelecer uma relação com a verdade totalmente diversa da que houvera antes, isto é, atua e influencia a realidade social, molda afetos, desejos, percepções e significações.

A mídia encena uma "nova moralidade objetiva", prescritiva, que cria identidades culturais e negocia com o instituído ao reiterar o familiar e tradicional, mas também ao propor mudanças. Sodré (2006, p. 30) usa a expressão "eticidade moralista da mídia" para explicar este fenômeno. O que a midiatização produz são direcionamentos ao que se deve ter ou ser para se adequar a um modelo de sucesso e aceitação. Modelo esse que valoriza comportamentos e escolhas individualistas, hedonistas e intensas, em consonância à sociedade de mercado, dentro de parâmetros morais que se alargam e se estreitam segundo interesses político-econômico-ideológicos. A inobservância dessas prescrições gera sentimentos de inadequação, vergonha e inferioridade.

Masterman (1985, p. 5) ressalta que a "mídia nos diz o que é importante e o que é trivial, a partir do que noticia e ignora, do que amplifica e do que silencia ou omite." O que atrai ou não os "olhares das mídias" (lentes, flashes, primeiras páginas e telas) está regulado por interesses políticos e ideológicos e as escolhas são forjadas por mecanismos outros que não a curiosidade desinteressada, a relevância social ou o mero entretenimento. A informação veiculada na televisão por meio de uma linguagem instantânea e fragmentada, esvaziada de historicidade, de causas e efeitos, torna-se facilmente substituível por outra mais atual.

Silverstone (2002, p. 75) alerta que a vulnerabilidade às mídias não é igual em todas as pessoas. Tem relação com o gênero, a idade, a classe, a nacionalidade, a escolaridade, de acordo com variáveis quase infinitas sendo, por conseguinte, imprevisível. Este autor entende que criamos, estamos e somos na mídia, tanto material como simbolicamente, e podemos distinguir entre fantasia e realidade preservando uma distância crítica mínima do que vemos, lemos e ouvimos. No entanto, admite que o nosso filtro tem como base o que conhecemos, o que acreditamos e que ignoramos muita coisa. Com as tecnologias da imagem - entre as quais se inclui o computador - o receptor passa a acolher o mundo a partir de representações que estabelecem 
outro espaço-tempo social, imaterial, ancorado no fluxo eletrônico. Para Sodré (1973, p. 60), o que os audiovisuais favorecem, mais do que os meios escritos ou sonoros,

são os processos de projeção (o receptor desloca suas pulsões para os personagens do vídeo), identificação (o receptor torna-se inconscientemente idêntico a um personagem no qual vê qualidades que gostaria ou julga que lhe pertençam) e empatia (conhecimento que o receptor tem do comunicador, colocando-se mentalmente em seu lugar).

As mídias eletrônicas atendem à busca pelo novo. Independentemente do que veiculam, de formatos, temas e abordagens, há um significado inerente ao meio que, tanto para McLuhan (1995), nos idos de 1960, como para Sodré (2002), é a atualidade. McLuhan traz ricas contribuições para pensar o significado simbólico das mídias eletrônicas a despeito de críticas importantes e fundamentadas a aspectos de sua teoria. ${ }^{4}$ Com seu pensamento sintético e pragmático formulou a máxima "o meio é a mensagem” que nos permite ampliar a análise do conteúdo para a estrutura e linguagem do meio e compreender como a forma ao mesmo tempo interfere e é conteúdo.

Uma das facetas mais importantes na atualidade para a teoria da comunicação social é a dimensão que o consumo assume na vida prática e na produção de significados. Ele está na esfera central do existir cotidiano e do viver em comunidade no capitalismo pós-moderno. O consumo é hoje o que nos diferencia no mundo e, ao mesmo tempo, o que nos homogeneíza. Ao consumir existimos, ao consumir imagens consumimos bens econômicos, culturais e simbólicos. Silverstone (2002, p. 150) salienta que o consumo não pode ser considerado simplesmente como supérfluo, como prática individual e periférica na organização social. Consumo, para este autor, é uma exteriorização de identidade e a mídia exerce um papel fundamental nesse processo, pois

consumimos a mídia. Consumimos pela mídia. Aprendemos como e o que consumir pela mídia. Somos persuadidos a consumir pela mídia. A mídia, não é exagero dizer, nos consome. [...] Consumimos objetos. Consumimos bens. Consumimos informação. Mas, nesse consumo, em sua trivialidade 
cotidiana, construímos nossos próprios significados, negociamos nossos valores e, ao fazê-lo, tornamos nosso mundo significativo. Sou o que compro, não mais o que faço ou, de fato, penso. E assim, espero, é você também. (SILVERSTONE, 2002, p. 150).

Masterman (1985, p. 4), em período anterior, questiona a crença comum de que a função primordial das mídias seja prover as pessoas de notícias, informação e entretenimento. Para ele as mídias "são Indústrias da Consciência, responsáveis não por distribuir simples informação sobre o mundo, mas por divulgar modos de ver e entender essa informação." Segundo o autor

a mídia de massa é mais e mais responsável por prover a base na qual grupos e classes constroem uma imagem dos modos de vida, significados, práticas e valores sobre outros grupos e classes. [...] Esta é a primeira das grandes funções culturais da mídia moderna: a provisão e construção seletiva de conhecimentos sociais. (MASTERMAN, 1985, p. 21).

Em seu livro seminal Teaching the Media, Masterman (1985) traz contribuições significativas para o estudo dos produtos midiáticos ao afirmar que suas construções precisam ser analisadas sob quatro aspectos. O primeiro deles, "as fontes, origens e determinações das construções midiáticas"; o segundo é relativo à "dominância técnica e aos códigos empregados pela mídia para nos convencer da realidade de suas representações"; em terceiro "a natureza da realidade construída pela mídia, os valores implícitos nas representações midiáticas" e, por último, "as formas/caminhos com que as construções midiáticas são lidas ou recebidas por suas audiências”. Ainda que não se faça um estudo que separe de forma tão sistemática esses quatro aspectos é importante considerá-los para evitar análises fragmentadas e incompletas, incapazes de abarcar as imbricadas mídias audiovisuais. ${ }^{5}$

\section{O endereçamento das Mídias}

Ao elaborar programas para serem divulgados em veículos de comunicação de massa (cinema, televisão, internet) diretores, produtores 
e roteiristas, espelham, com mais ou menos consciência, um público específico que desejam atingir, cujo perfil geral acreditam conhecer. As telenovelas, por exemplo, são obras em aberto que vão sendo construídas e modificadas a partir da interação com o público. Suas diferentes tramas, conflitos, narrativas vão sendo endereçadas e re-endereçadas às pessoas, grupos, comunidades, a todos os membros da família, sejam eles homens, mulheres, adolescentes ou crianças, porque há nas entrelinhas designações de faixa-etária, classe social, gênero, grupo de pertencimento, escolaridade, enfim, múltiplas identidades.

Há intenções que permeiam os programas de forma invisível, calcando a escolha das imagens, dos personagens, das histórias, da estética, criando uma estrutura narrativa que nos parece natural ou aleatória, mas que vai traçar modos de endereçamento a um destino final, o destino “certo". Há, porém, variáveis que não podem ser controladas por quem faz a programação, que lhes escapam, pois dizem respeito a cada receptor individual e coletivamente, mas também a cada realizador, pertencente a grupos e categorias que influenciam suas produções e podem não estar em consonância com o público desejado. Os endereçamentos podem, assim, errar o alvo, e muitas vezes o fazem. As pessoas podem questionar aspectos de um determinado produto televisivo, não gostar dele por diversas razões ou mesmo se recusar a assisti-lo. O espectador pode não ter gostado da chamada ${ }^{6}$ para o programa, pode ter sido influenciado por amigos que o assistiram e o rejeitaram, pode ter escolhido assistir outra coisa no mesmo horário ou não assistir à coisa alguma.

Os endereçamentos de um programa tem relação com o prazer em assisti-lo e com as interpretações que o espectador faz de seus conteúdos. A identificação com um determinado personagem pode significar que o espectador acredita ser como aquele adolescente ou adulto representado ou deseje ser como ele. Esta identificação, calcada em signos de desejo embutidos na representação daquela posição-de-sujeito, seduz e oferece recompensas ao modelo representado: status, sucesso, beleza, notoriedade, riqueza, poder etc.. Segundo Ellsworth (2001, p. 26) "por meio da exclusão ou do ridículo ou da punição inscrita na narrativa, querer ser uma garota (ou ser negro/a, ou gay, ou gordo/a, ou falante de espanhol, ou ser uma garota e uma ou outra dessas identidades) não é a coisa certa." Os endereçamentos contribuem para a formação de identidades e subjetividades específicas, 
socialmente aceitas e valorizadas que têm relação direta com desejos e sonhos de cada um.

O fato de ser um espectador crítico não diminui o prazer que se possa ter em assistir a um programa de auditório ou um comercial criativo porque a recepção não acontece apenas em termos racionais. Os prazeres, identificações, modos de recepção operam de maneira complexa porque as pessoas não são detentoras de características puras e fixas de modo que haja pessoas "críticas" e "cultas" e outras "deslumbradas" e "ignorantes". Somos críticos em determinados momentos e extremamente ingênuos no momento seguinte. Deslumbramo-nos com paisagens de grande beleza cênica e ignoramos sumariamente imagens grotescas da violência nas favelas brasileiras. As leituras são extremamente complexas e, por vezes, contraditórias. Por isso, leitores ditos críticos não deixam de se rejubilar frente a um bom filme de ação ou a um capítulo decisivo de uma telenovela. As recompensas que as telenovelas trazem - o simples descanso, o "esvaziamento da mente" ou os sentimentos de prazer - podem estar ligados ao final feliz, ao casamento dos mocinhos, ao sucesso profissional e afetivo, à trama bem urdida, ao humor escrachado. Tudo isso está lá, nos interpelando, nos convidando a ler a partir dos endereçamentos que mais nos cativem, dependente de nossa motivação. Masterman (apud ELLSWORTH, 2001, p. 17) afirma que o público - e ele se inclui - é compelido a ocupar uma posição física determinada pela câmera que forma um lugar social, relacionado às posições ideológicas; segundo ele "maneiras 'naturais' de examinar e dar sentido à experiência."

A teoria dos modos de endereçamento, proveniente dos estudos de cinema, segundo Ellsworth (2001), analisa o processo de feitura e de recepção de audiovisuais sob uma ótica ampla que envolve as dinâmicas sociais e as relações de poder. Essa definição aproxima-se muito do viés analítico dos estudos latino-americanos, segundo os quais a recepção é influenciada pela sociabilidade e identidades culturais dos indivíduos. Martín-Barbero (2006) destaca as mediações, estruturantes e múltiplas, que incidem nos processos comunicativos e os compõem, orientando as produções de sentido. A teoria dos modos de endereçamento tem em comum com a teoria latino-americana da recepção o fato de considerar que a recepção opera sob influência de uma rede de experiências, textos e contextos, provenientes de âmbitos diversos, das vivências individuais e coletivas. Além disso, ambas consideram que não há um ajuste perfeito entre 
as expectativas de realizadores e a recepção do público, que não é possível obter respostas exatas, previsíveis e que há uma resistência racional, fruto de um sujeito capaz de fazer escolhas e de ressignificar o que recebe. Não obstante, a teoria dos modos de endereçamento enfatiza a existência de uma reação que escapa ao controle do sujeito, que não é consciente e provém de mecanismos outros que não a escolha e a racionalidade.

As narrativas televisivas possuem dimensão simbólica e intencional e, como meio e produto, emitem informações, conceitos e valores todo o tempo. Os ângulos, os planos, os ritmos que compõem as imagens, assim como as luzes, as sombras, as falas, os sons, são escolhidos intencionalmente por profissionais que dominam as técnicas da linguagem televisual, assim como a ordem da programação. $\mathrm{O}$ fato de despender dois ou cinco minutos transmitindo uma informação; de abordar um tema como agenda positiva, como denúncia ou de forma sensacionalista; de escolher determinada matéria para abrir ou fechar um bloco do telejornal; de veicular programas para adolescentes, de uma forma e não de outra, busca atingir um efeito. Em suas vinhetas, cenas, cenários, trilhas sonoras e tramas, com linguagem própria e complexa, as telenovelas, citando um exemplo, veiculam conteúdos intencionalmente direcionados, objetivos e subjetivos, que buscam influenciar ou "educar" os espectadores. Ao fazer escolhas, ao eleger uma concepção de adolescente e de adolescência, por exemplo, calcada em referenciais de classe média alta de grandes metrópoles, as emissoras estão se posicionando, reforçando o que desejam valorizar. "As representações aparecem no contexto discursivo como formas casuais, meras insinuações, 'pistas' visuais ou mesmo como 'cenário' dado como 'normal' ou 'padrão', que acaba naturalizando a representação" defende Soares $(2007$, p. 6). Esse processo é intensificado quando se trata de imagens, sejam elas fotográficas, digitais, estáticas ou em movimento. Os discursos são materializados em determinadas "composições de imagens pictóricas ou dramatúrgicas, audiovisuais, aparentemente colhidas no mundo empírico, sem intervenção ativa de ninguém, as quais são elevadas à categoria de representantes de pessoas, situações, fatos.”

\section{Considerações finais}

Mudanças tecnológicas e sócio-culturais, de produção, acesso e recepção de mensagens operam em ritmos e intensidades distintas, o 
que faz com que variadas instituições, meios, formatos e linguagens coexistam, produzindo o que Orozco-Gómez (2006) denomina destempos, superposições de temporalidades, entre o pré-moderno, o moderno e o pós-moderno. Assim acontece com a relação entre as mídias e a escola.

A escola, espaço de formalização e uniformização do saber, de domínio e ratificação de um conhecimento consensuado, está ligada ao oficioso, às regras, aos conteúdos acordados e atua apoiada em um modelo de conhecimento dito "universal" que legitima um determinado conhecimento escolar que se materializa no currículo. Santos (1999, p. 12) afirma que este modelo de racionalidade foi constituído a partir da revolução científica do século XVI e sedimentado nos séculos posteriores, principalmente no domínio das ciências naturais. Apenas no século XIX este modelo de racionalidade se estendeu às ciências sociais que passa a policiar ostensivamente os conhecimentos considerados não-científicos: o senso-comum e as chamadas humanidades e/ou estudos humanísticos (estudos históricos, filosóficos, jurídicos, literários, filosóficos e teológicos). Esse modelo global de racionalidade científica, segundo o autor, tornou-se totalitário na medida em que nega o caráter racional de outras formas de conhecimento que não as pautadas em seus princípios epistemológicos e metodológicos. "Ao contrário da ciência aristotélica, a ciência moderna desconfia sistematicamente das evidências da nossa experiência imediata", resume Santos (1999, p. 13).

Dentro desta perspectiva, o conhecimento é selecionado, organizado, hierarquizado e passa a integrar as disciplinas que compõem a estrutura curricular da escola. Mas a estrutura escolar e o currículo oficial, a despeito de se justificarem e se afirmarem como necessários, por questões práticas e didáticas diretamente relacionadas ao tipo de trabalho da escola e por uma necessidade social de regular e disseminar regras de convivência e conhecimentos comuns, não dão conta das necessidades, individualidades e desejos dos alunos. Uma das causas, acreditamos, é o fato de haver uma oferta única para todos de como aprender os conteúdos, em geral os mesmos, dentro de disciplinas comuns, com as mesmas linguagens e formatos e professores com formação acadêmica semelhante. No entanto, os alunos provêm de diferentes lugares sociais, não possuem as mesmas experiências e referências, as mesmas habilidades, os mesmos desejos, sentimentos e têm um acesso cada vez mais amplo a uma gama 
de informações e novidades atualizadas a cada segundo nos canais de televisão e sites da internet.

Vivemos um momento cheio de referências em que se misturam várias formas de aprender, no qual o quarto de televisão, os corredores da escola, as lan houses tornam-se também fontes de conhecimento e ambientes de aprendizagem. Esses conhecimentos, não certificados pela academia, rompem e deslocam as relações de poder estruturadas no sistema educativo: da academia para as mídias, da escola para a televisão, do professor para o aluno etc. Os espaços hoje se interpenetram e os meios de comunicação de massa passam a fazer parte da educação de jovens e crianças e colocam grandes desafios para a instituição escolar, muitas vezes contrária a conhecimentos e comportamentos que provêm dos próprios alunos e das mídias. Martin-Barbero (2006, p. 55) afirma que vivemos em 'sociedades do desconhecimento', isto é, sociedades que não reconhecem a pluralidade de saberes e culturas e não as incorporam/integram às sociedades e seus sistemas educativos.

Esse fato gera situações em que a autoridade que foi conferida à escola ao longo da história, bem como seu primaz domínio sobre os conhecimentos, é contestada, assim como suas metodologias, livros didáticos e professores. A escola, na modernidade líquida, torna-se uma instituição necessária, porém enfraquecida, com cada vez mais dificuldade em 'tocar' e 'convocar' os alunos que surgem nestes novos tempos. Os endereçamentos da escola, assim como acontece com as mídias, mas talvez agora com maior frequência, erram os alvos.

O que temos hoje, em resumo, é uma escola que precisa negociar com uma sociedade midiatizada em que a televisão e a internet expõem crianças e jovens a referências não lineares, ${ }^{7}$ distantes daquelas provenientes do saber escolar instituído e com as quais muitas vezes os alunos tomam para si a busca da informação, pautada, em grande medida, por seus interesses e desejos pessoais. Compartilhamos, então, de uma reflexão realizada por Fischer (1998, p. 108, grifos do autor): afinal os programas televisivos não seriam espaços de "representação de interesses específicos"? A autora se pergunta:

Será que os programas de televisão recebidos e consumidos por nossas crianças - sejam eles 
telenovelas como Viralata ou Malhação, ou mesmo um programa como o da Angélica, só para citar alguns exemplos da Rede Globo - não estariam respondendo de uma forma muito eficaz a alguns anseios, obviamente criados e reforçados socialmente, mas que existem de fato para numerosos grupos sociais, especialmente para contingentes significativos de crianças e adolescentes?

A mídia televisiva possibilita experiências estéticas e sensoriais de desejo e prazer ao oferecer aos espectadores um rol de atrativos - novidade, emoção, fruição - com a intenção de cativá-los e transformá-los em audiência. Com sua grande capacidade de construção e reconstrução de seus produtos parece conviver em harmonia com a mudança, de modo que o que foi dito/mostrado hoje será revisto e muito comumente contestado amanhã. Sem pudores. O passado, para este meio, faz parte de uma memória necessária, não dogmática, que sobrevive justamente da necessidade de evolução e serve como referencial a ser superado. A composição e ordem de veiculação fazem com que 'velhas' imagens se tornem 'novas'. As cenas são gravadas, exibidas, regravadas, fundidas a outras, compostas em sequências que criam novos significados.

Segundo Ellsworth (2001) para transpor a teoria dos modos de endereçamento para o currículo e espaço escolar, em busca de uma nova visão crítica e transformadora, é necessário considerar três aspectos:

- que a diferença entre o que os modos de endereçamento buscam atingir e o que de fato atingem é um espaço social, com suas relações históricas de poder e cultura;

- que essa diferença de emissão e recepção opera em nível inconsciente e, por isso, escapa à vigilância e controle dos professores sobre os alunos;

- que essa diferença entre alvo pretenso e alvo efetivamente alcançado pode ser um recurso positivo a serviço do currículo e dos professores.

Os educadores, sejam suas metodologias e práticas pedagógicas tidas como dialógicas e atualizadas, acertarão o que se propõem em alguns alunos e errarão em outros. Essa interação complexa, esse processo de 
acerto e erro, faz parte da dinâmica de endereçamento e não deve ser encarado como ameaça à instituição escolar ou à autoridade intelectual do professor. $\mathrm{O}$ erro pode ser encarado não como derrota, mas como indicativo de uma necessidade de mudança, como estímulo para rever culturas e conhecimentos, como motivação para adaptar forma e conteúdo para atender o público específico em busca de aprimoramento.

\section{Notas}

1 Thompson empreendeu a revisão da obra de Williams no seu livro The Long Revolution. Revisão essa, que Williams, obliquamente, considerou em seus textos posteriores (HALL, 2003).

2 Thomas H. Marshall, em 1949, propôs a primeira teoria sociológica da cidadania, desenvolvendo os direitos e obrigações inerentes à condição de cidadão. Em sua obra Cidadania, classe social e status Marshall divide o conceito de cidadania em três partes ou elementos: civil, político e social (MARSHALL, 1967).

3 "Massa" é definida por Blumer (1987, p. 177) como grupo, elementar e espontâneo, composto por indivíduos anônimos, originários de qualquer grupo e categoria social, que não interagem, trocam pouca ou nenhuma experiência, encontram-se, em geral, fisicamente separados e participam de um comportamento de massa. Essas características tornam a massa uma organização frágil, incapaz de agir de forma integrada.

4 As teorizações de McLuhan foram e ainda são muito criticadas, rotuladas de deterministas, excessivamente otimistas, ao propor que os meios de comunicação criam uma "aldeia global" porque as tecnologias elétricas produzem interação e a audiência das massas seria uma nova forma política de participação desalienante que iria mudar o mundo. Não obstante, vários autores reconhecem sua contribuição para analisar os meios de comunicação de massa e apropriam-se de suas reflexões sobre as evoluções tecnológicas ao longo dos tempos (da escrita e da roda aos circuitos elétricos e seus produtos), do conceito de "prótese tecnológica" e da máxima "o meio é a mensagem". É importante considerar o contexto e o tempo histórico em que o autor formulou seus conceitos, décadas de 1960 e 70, nos Estados Unidos, momento de disseminação da televisão e 
de contraposição à Teoria Crítica de Adorno e Horkheimer. Cf. Mcluhan (1995), Mattelart, A. e Mattelart, M. (2001).

5 Sobre a obra de Len Masterman cf. Belloni (2001).

6 Chamadas são anúncios de programas da emissora veiculados nos intervalos comerciais. São convites ao espectador visando despertar sua curiosidade e interesse por programas específicos.

7 Sobre a relação de crianças e adolescentes com as mídias eletrônicas, computador e televisão cf. Fantin e Girardello (2008).

\section{Referências}

ARAÚJO, S. M. da S. Cultura e educação: uma reflexão com base em Raymond Williams. In: REUNIÃO ANUAL DA ASSOCIAÇÃO NACIONAL DE PÓS-GRADUAÇÃO E PESQUISA EM EDUCAÇÃO, 27, Caxambu, MG. Anais... Caxambu, MG, 2004. GT: Movimentos Sociais e Educação.

ARISTÓTELES. Poética. Buenos Aires: Quadrata, 2002. . Ética a Nicômaco. São Paulo: Editora Abril Cultural, 1973. (Coleção Os Pensadores).

BAUMAN, Z. Globalização: as consequências humanas. Rio de Janeiro: Jorge Zahar Editor, 1999. . Modernidade líquida. Rio de Janeiro: Jorge Zahar, 2001. . Comunidade. Rio de Janeiro: Jorge Zahar, 2003. . Identidade. Rio de Janeiro: Jorge Zahar, 2005.

BELLONI, M. L. O Que é mídia-educaşão. Campinas, SP: Autores Associados, 2001.

BLUMMER, H. A massa, o público e a opinião pública. In: COHN, G. (Org.). Comunicação e indústria cultural. 5. ed. São Paulo: T. A. Queiroz, 1987.

CANCLINI, N. G. Consumidores e cidadãos: conflitos multiculturais da globalização. 5. ed. Rio de Janeiro: UFRJ, 2005. 
CANCLINI, N. G. A Globalização imaginada. São Paulo: Iluminuras, 2003.

ELLSWORTH, E. Modos de Endereçamento: uma coisa de cinema; uma coisa de educação também. In: SILVA, T. T. da (Org.). Nunca fomos humanos: nos rastros do sujeito. Belo horizonte: Autêntica, 2001.

FANTIN, M.; GIRARDELLO, G. (Org.). Liga, roda, clica: estudos em mídia, cultura e infância. Campinas, SP: Papirus, 2008.

FISCHER, R. M. B. A Construção de um discurso sobre a infância na televisão brasileira. In: PACHECO, E. D. (Org.) Televisão, criança, imaginário e educação. Campinas, SP: Papirus, 1998. p. 107-116.

HALL, S. A identidade cultural na pós-modernidade. 7. ed. Rio de Janeiro: DP\&A, 2005.

. Da Diáspora. Belo Horizonte: Ed. FMG, 2003.

HOGGART, R. The uses of literacy: aspects of working-class life with special reference to publications andentertainments. London: Chatto and Windus, 1957.

MCLUHAN, M. Os Meios de comunicação como extensões do homem. 10. ed. São Paulo: Cultrix, 1995.

MARSHALL, T. H. Cidadania, classe social e status. Rio de Janeiro: Zahar Editores, 1967.

MARTÍN-BARBERO, J. Tecnicidades, identidades, alteridades: mudanças e opacidades da comunicação no novo século. In: MORAES, D. (Org.). Sociedade midiatizada. Rio de Janeiro: Maud, 2006. p. 51-79.

MASTERMAN, L. Teaching the media. New York: Routledge, 1985.

MATTELART, A.; MATTELART, M. História das teorias da comunicação. São Paulo: Loyola, 2001.

OROZCO-GÓMEZ, G. Comunicação social e mudança tecnológica: um cenário de múltiplos ordenamentos. In: MORAES, D. (Org.). Sociedade midiatizada. Rio de Janeiro: Maud, 2006. p. 81-98.

SANTOS, B. S. Um discurso sobre a ciência. Porto: Afrontamento, 1999.

SILVERSTONE. R. Por que estudar a mídia? São Paulo: Loyola, 2002. 
SOARES, M. C. Representações da cultura mediática: para a crítica de um conceito primordial. In: ENCONTRO DA COMPÓS, 16., 2007, Curitiba, PR. Anais... Curitiba, PR: Associação Nacional dos Programas de Pós-Graduação em Comunicação, 2007. Grupo de Trabalho Cultura das Mídias.

SODRÉ, M. A Comunicação do grotesco. Petrópolis, RJ: Vozes, 1973.

SODRÉ, M. Antropológica do espelho: uma teoria da comunicação linear e em rede. Petrópolis, RJ: Vozes, 2002.

SODRÉ, M. Eticidade, campo comunicacional e midiatização. In:

MORAES, D. (Org.). Sociedade midiatizada. Rio de Janeiro: Maud, 2006. p.19-31.

THOMPSON, E. P. The making of the english working class. London:

Penguin Books Ltd, 1991.

WILLIAMS, R. Cultura. Rio de Janeiro, Paz e Terra, 1992. . Cultura e sociedade: 1780-1950. São Paulo, Editora Nacional, 1969. 


\section{Culture, media and identities in post-modernity}

\section{Abstract:}

This article relates the phenomenon of globalization to cultural questions, the formation of new identities and the growing expansion of the media in contemporary societies. We discuss the construction of new cultural identities that emerge in the face of globalization, fruit of the interwoven relationship of individual, collective and media identities. We contextualize the space and place that the electronic medias occupy in these times of post-modernity based on the concept of mediazation of society and the possibilities that the theory of modes of addressing brings to an understanding of the relationship between media, curriculum and school.

Key words: Identity. Media. Identity and culture in post-modernity.

\section{Lidia Miranda Coutinho}

Instituto Sapientia/FEPESE

Endereço: Av. Luiz Boiteux Piazza, 1302

Cachoeira do Bom Jesus - Sapiens Parque - Florianópolis

Tel: (48) 99159855

E-mail: lidiacoutinho@yahoo.com.br

\section{Elisa Maria Quartiero}

Rua: Elmo Kiseski, 80, apto 201

Florianópolis - SC

Tel: (48) 33331024

E-mail: f2emq@udesc.br

\section{Culturas, medios e identidades en la pos- modernidad}

\section{Resumen:}

En el presente artículo buscamos relacionar el fenómeno de la globalización con las cuestiones culturales, la formación de nuevas identidades y la creciente expansión de los medios en la sociedad contemporánea. Discutimos la construcción de nuevas identidades culturales que emergen en el contexto da la globalización, fruto de la imbricada relación de las identidades individuales, colectivas y mediáticas. Contextualizamos el espacio y el lugar que los medios electrónicos ocupan en estos tiempos de pos-modernidad a partir del concepto de mediatización de la sociedad y discutimos las posibilidades que la teoría de los modos de dirección proporciona para la comprensión de la relación entre los medios, el currículo y la escuela.

Palabras-clave: Identidad. Medios. Identidad y cultura en la pos-modernidad.

Recebido em: 26/3/2009

Aprovado em: 30/5/2009 